\title{
Chipping of cratons and breakup along mobile belts of a supercontinent
}

\author{
K. Veeraswamy and U. Raval \\ National Geophysical Research Institute, Hyderabad, India \\ (Received September 23, 2003; Revised April 30, 2004; Accepted May 3, 2004)
}

\begin{abstract}
Probably one of the most significant heterogeneities of a continental lithosphere is the noticeable difference in the thickness and properties of its cratonic and mobile parts. The trans-continental mobile belts (Paleoorogens/paleo-sutures) represent a relatively thinner, warm, wet and weak lithosphere, which makes it more vulnerable to episodic mantle (or plume) upwellings and compressional forces. Here evidence is presented from the Indian continental lithosphere to show that these properties of mobile belts (MB) facilitate channeling of thermomagmatic fluxes (TMF) in both lateral as well as vertical directions. This, to a major extent, can account for the observed concentration (or focusing) of geophysical anomalies, tectonomagmatic features and strain along these MBs. In addition, a closer examination of the three continental breakups of Greater India since the Cretaceous reveals that the combination of a sufficiently weakened MB and mantle plume could become 'fatal' for the supercontinental stability. On the other hand, the thick $(>200 \mathrm{~km})$ or deep-rooted continental lithosphere beneath cratons is characterized by a relatively cold and dry lithosphere, which resists remobilization. From this relative impenetrability, TMFs are channeled mostly through the MBs following the long-term stability of the cratonic lithosphere. This difference in cratonic and MB regimes results in strongly heterogeneous thermal blanketing. However, in certain situations, the edge of a cratonic region may also get chipped-off following a number of thermotectonic rejuvenations of adjoining MBs - as exemplified by the breakup of the Antongil and Masora cratonic blocks (now lying on the Madagascar) from the Western Dharwar craton (India) during the IndiaMadagascar separation. From the study of supercontinental dispersals, it seems that the processes of breakup along pre-existing mobile belts may be globally applicable. This is, at times, also accompanied by chipping of cratons.

Key words: Supercontinental breakup, mobile belt, thermomagmatic flux, mantle plume, chipping and craton.
\end{abstract}

\section{Introduction}

The two-layer convection process inside the Earth and the resulting motion and dynamics of the overlying lithosphere (which has been termed plate tectonics) are able to explain most of the geophysical, geological and tectonic manifestations along the plate boundary. However, many intraplate (or mid-continental) features are not explicable in terms of plate tectonics alone and necessitate other processes like plume tectonics. For example, where and how a supercontinent splits is still not clear. The breakup apparently involves characterization of the internal structure of the continental lithosphere (CL) and a force external to it. It has been suggested that the required forces (external to the CL) are often due to mantle plumes (White and McKenzie, 1989; Storey, 1995; Courtillot et al., 1999; Dalziel et al., 2000); while the internal structure of the CL is defined by the pre-existing weak zones and/or palaeo-orogenic corridors, as emphasized by Dunbar and Sawyer (1989), Dalziel et al. (2000) and Tomassi and Vauchez (2001). The combination of these two factors, which could govern the breakups, however, requires further investigation. Around $130 \mathrm{Ma}$ India, along with Madagascar and the Seychelles, separated from Eastern Gondwanaland.

Copy right (c) The Society of Geomagnetism and Earth, Planetary and Space Sciences (SGEPSS); The Seismological Society of Japan; The Volcanological Society of Japan; The Geodetic Society of Japan; The Japanese Society for Planetary Sciences; TERRAPUB.

\section{Three-Phase Breakup}

The Indian CL consists of four Archaean cratons, viz. Dharwar, Bastar, Singhbhum, and Bundelkhand (Radhakrishna and Naqvi, 1986), surrounded by MBs (Fig. 1(a)). These MBs represent palaeoconvergence (or suture) zones (Naqvi and Rogers, 1987). The idea of hotspots was put forward in a classical paper by Wilson (1963) to explain the intraplate, the Hawaiian volcanism and associated magmatic (OIB type) island chains. This study was extended by Morgan (1971) to the concepts of a mantle plume which involves upwelling of cylindrical ( $\sim 100 \mathrm{~km}$ diameter) plume conduits from the lower mantle and, on reaching the base of the lithospheric plate, the head of this plume can spread laterally to a large dimension (1000-2000 km diameter). Many geological, geochemical and isotopic features-which do not find explanation in the plate tectonics — could be explained by plume tectonics (Davies, 1999). White and McKenzie (1989) have attributed the rifting of supercontinents and associated flood basaltic magmatism to the presence of plumes near the breakup or triple junctions (Burke and Dewey, 1973). Campbell and Griffiths (1990) have also discussed the evolution of flood basalts due to mantle plumes. Ernst and Buchan (2001) and Condie (2001) describe various aspects related with mantle plumes, in particular an episodic growth of the crust during superplume activities. Larson (1991a, b) has described the consequences of the late Cretaceous superplume.

Following Storey (1995), and for T>130 Ma, it is known 


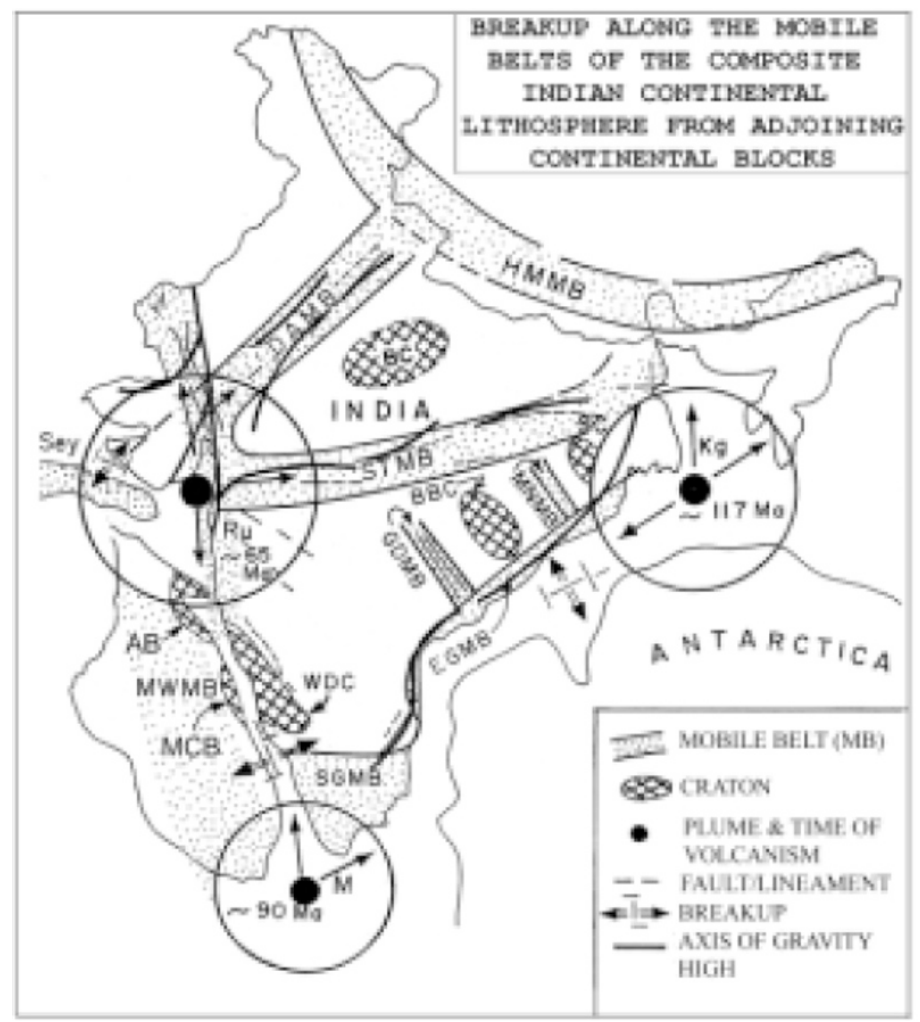

Fig. 1(a). Cratons (C) and first order mobile belts (MBs) of the Indian continental lithosphere (I-CL). It may be noticed that there is a concentration of faults/lineaments (dashed line) and axes of gravity high (thick line) within the MBs. Abbreviations: DAMB-Delhi Aravalli, STMB-Satpura, EGMB - Easternghat, SGMB — Southern granulite, GDMB — Godavari, MNMB-Mahanadi, MWMB-Madagascar west coast, HMMB-Himalayan mobile belts and BC-Bundelkhand, WDC_-Western Dharwar, BBC_-Bastar Bhandara, SC_-Singhbhum cratons. Probable positioning of mantle plumes ( $\mathrm{Ru}$-Reunion, $\mathrm{Kg}$ - Kerguelen and $\mathrm{M}$-Marion) at different geological times is also depicted. Flow direction of thermomagmatic flux is shown by arrow.

that India lay close to a number of hotspots (Kerguelen/Crozet, Marion and Reunion), possibly part of a Cretaceous superplume (Fig. 1(a)). A number of geophysical anomalies and geotectonic features have been attributed to the interaction of the Indian lithosphere with these plumes since the Cretaceous (Raval, 1989; Kent, 1991; Basu et al., 1993; Singh and Meissner, 1995; Storey et al., 1995; Atchuta Rao et al., 1996; Mall et al., 1999; Mishra et al., 1999; Courtillot et al., 2000; Raval and Veeraswamy, 2000, 2003; Anil Kumar et al., 2001; Tewari et al., 2001; Mukhopadhyay, 2002; Roy, 2004; Mahoney et al., 2002). These plumes (P) appear to have affected the MB network of India.

\subsection{Separation from Antarctica ( 130-120 Ma)}

The separation from Antarctica took place along the Proterozoic Easternghat Mobile Belt (EGMB) during this phase and, the Kerguelen/Crozet/Marion plumes lay close to the EGMB (Fig. 1(a)). Interaction between the plumes and the overlying CL results in doming above the plumehead. A consequent extension would significantly affect the MBs which fall in the extensional field caused by doming (Burke and Dewey, 1973). The corresponding crust-mantle interaction evidently reached a level beyond the threshold breaking stress and resulted in the separation of India from Antarctica along the EGMB, as shown in Fig. 1(a) (Larson, 1991a,b). A large, igneous province (LIP) at $\sim 117$ Ma (Baksi, 1995) indicates a long incubation for the Kerguelen plume.

\subsection{Separation from Madagascar ( 90 Ma)}

Here the influence of the Marion plume has been invoked (Storey et al., 1995). Continuity between the southern Granulite mobile belt (SGMB) of India and Madagascar (Fig. 1(a)); and episodic mobilizations of the Madagascan lithosphere since the late Archaean (Collins et al., 2001), imply that, prior to breakup ( $\mathrm{T}>90 \mathrm{Ma}$ ), Madagascar also constituted a part of the mobile network of Greater India (Raval, 1995), which linked the northern and southern MBs of Greater India. It implies that in the breakup along India's western margin too, a mobile belt and plume were involved. The trace and outburst of the Marion plume over Greater India is supported by large-scale magmatism (at $\sim 90 \mathrm{Ma}$ ) over juxtaposed mobile parts of the Madagascan and Indian CL (Storey et al., 1995; Radhakrishna et al., 1999; Anil Kumar et al., 2001). To further examine the similarity between Indian mobile belts and Madagascar, the geophysical anomalies, juxtaposition and geotectonic data over the Madagascan and Indian mobile belts are compared:

(a) Gravity: The average Bouguer gravity anomaly (BGA) values over different mobile belts of India are much higher (STMB: -30 mgal; DAMB: -20 mgal; EGMB: -20 mgal) than that over cratons (Western Dharwar: $-110 \mathrm{mgal}$; Bundelkhand: -70 mgal; Bastar-Bhandara: -70 mgal), while over the Madagascan mobile belt (Woollard, 1972), BGA exhibits an average value of -30 mgal (Fig. 1(b)), which is similar to that over the MBs of India. 


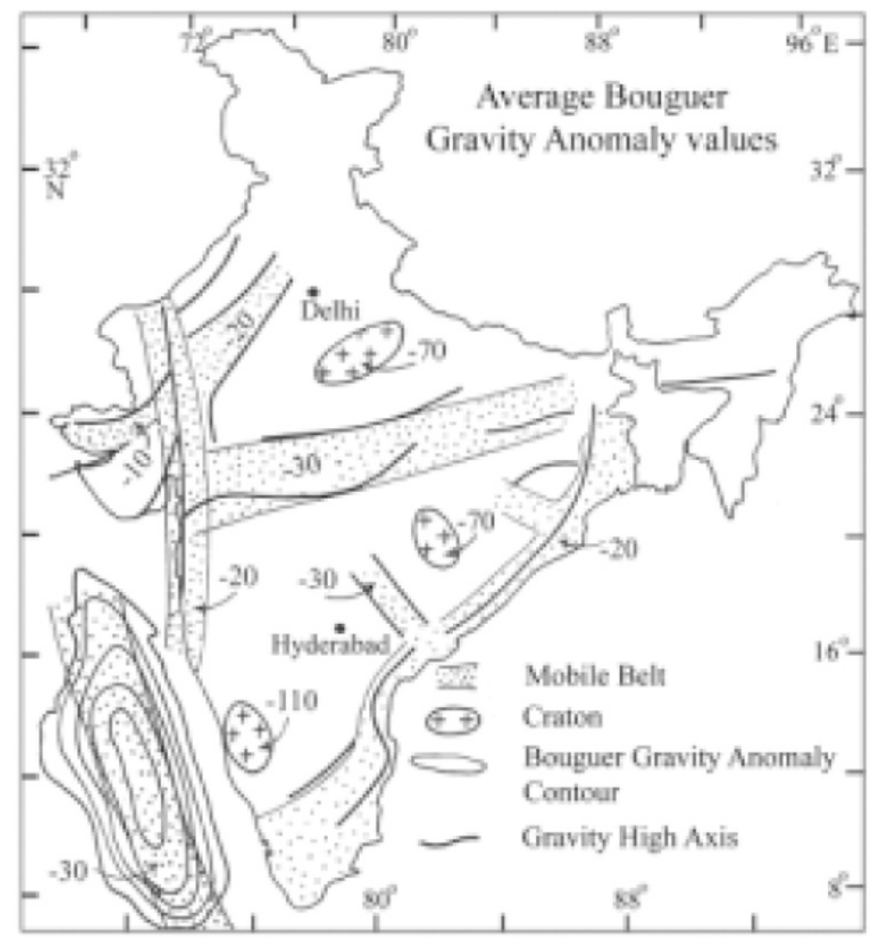

Fig. 1(b). Concentration of axes of Bouguer gravity anomaly highs along the mobile belts (modified from Verma, 1985). The average Bouguer gravity value over mobile belts is $\sim-30 \mathrm{mgal}$, which is higher than the average value over the cratons $(<-70$ mgal). It suggests that, as compared to cratons, the lithosphere beneath the mobile belts is thinner and denser; further the crust-lithosphere regime of Madagascar matches with the mobile belts of India. Values over Madagascar have been taken from Woollard (1972).

(b) Moho depths: Using the receiver function analysis, Moho depths under the eastern Dharwar craton (EDC) and other mobile belts have been estimated to be $\sim 34-40 \mathrm{~km}$ (Ravi Kumar et al., 2001; Gupta et al., 2003). From Fourno (1987), the Moho depths under Madagascar also do not exceed $40 \mathrm{~km}$, thus the crustal thickness under Madagascar resemble that under the EDC and Indian mobile belts.

(c) Seismicity and Tectonics: The distribution of epicenters over India reveals a conspicuous concentration (or channeling) of seismic deformation along the mobile belts (Raval, 1995). Distribution of seismic epicenters over most of Madagascar also supports its mobile nature (Fourno, 1987), while the WDC exhibits a lack of epicenters, thus indicating the stability (i.e. low strain rate) of the cratonic nuclei. Similarly, near-absence of epicenters over the Antongil and Masora blocks corroborates their cratonic characteristics.

(d) Juxtapositioning between India and Madagascar and use of geophysical anomalies: Studies into juxtapositioning invariably utilize geological, structural and/or metamorphic evidence. It is seen that in localizing the Archaean blocks over Madagascan (viz. Antongil and Masora-as suggested by Collins and Windley, 2002), vis-á-vis the WDC, use of the geophysical anomalies may provide additional constraints. For example, the two gravity lows $(\mathrm{L} 1, \mathrm{~L} 2)$ over the WDC seem to match those of the Antongil (AB) and Masora (MCB) cratonic strips. Further, the fast velocity zones (50-175 km depth) over the WDC, inferred from teleseismic tomography (Srinagesh, 2000), correlate with the gravity lows over WDC (NGRI, 1975) and these geophysical signatures appear quite contiguous with the cratonic strips or chips (Antongil and Masora) over Madagascar. (e) Breakup of the western edge of WDC: The migration of magma along the base of the cratonic keel towards the marginal MBs explains the concentration of kimberlites (and/or other fluids rising from deeper regions) near cratonmobile belt interfaces (Raval, 1998).

Similar chipping of cratons appears to have occurred also during the separation of Africa from Antarctica wherein a small chunk of the Kaapval part of the Kalahari craton in the Dronning Maud Land (Maudheim province, viz. Grunehogna province of Antarctica) appears to have chipped (Groenewald et al., 1991). Such chippings may be important in assessing the ancestry of cratonic strips/blocks which, at present, are widely separated. However, further confirmation of the chipping process necessitates comparison of geochemical/isotopic characteristics.

\subsection{Separation from the Seychelles ( $\sim 64 \mathrm{Ma})$}

Prior to breakup, the Seychelles and contiguous northwestern India lay close to a triple junction (Burke and Dewey, 1973; Biswas, 1987) between three MBs, as shown in Fig. 1(a), which came under the influence of the Réunion plume between 68-64 Ma (Sivaraman and Raval, 1995). Tucker et al. (2001) have considered the Seychelles as part of a larger MB consisting of NW India, Mozambique and Madagascar.

Thus, all these three separations of Greater India exhibit that its MBs became the foci of continental rifting and volcanism during various plume-CL interactions. To understand it further, the structure and properties of cratons and MBs need to be examined. 


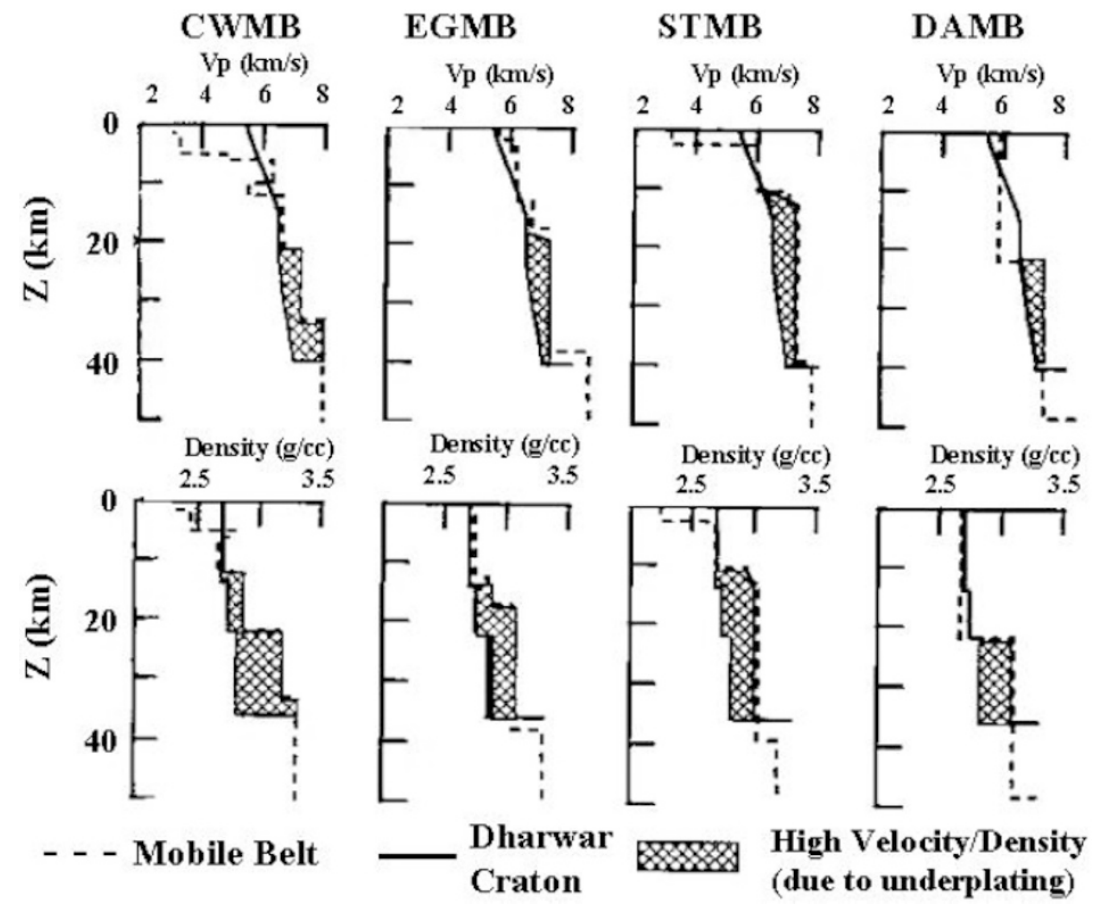

Fig. 2(a). Variation of seismic wave velocity ( $\mathrm{Vp}$ in $\mathrm{km} / \mathrm{s}$ ) and density (in $\mathrm{g} / \mathrm{cc}$ ) with depth beneath different MBs of the Indian subcontinent (modified from Kaila and Bhatia, 1981; Kaila et al., 1990; Tewari et al., 1991) is shown, vis-á-vis, as a variation of these parameters under the WDC. Both seismic wave velocity and density are greater beneath the MBs as compared to that under the cratonic region.

\section{Cratons and Mobile Belts}

A CL is composed of thick ( $\geq 180-250 \mathrm{~km})$, cold and rigid Archaean cratons and relatively weak, warm, hydrous and thinner ( $\sim 80-180 \mathrm{~km})$ younger (Proterozoic/Phanerozic) MBs along which the cratons are sutured/amalgamated (Raval, 1995; Tommasi and Vauchez, 2001). Thus, they would be vulnerable to reactivation. The cratons represent deep-rooted parts of the lithospheric column (thickness $>180-250 \mathrm{~km}$ ), and are relatively cold, dry and rigid (Jordan, 1975). Owing to these characteristics, the impressed thermomechanical forces find it difficult to penetrate/deform the cratons. In contrast, the mobile belts lithosphere is relatively thin $(70-150 \mathrm{~km})$, warm, weak and hydrous (or wet). In the case of Litho-Asthenosphere (including mantle plume) interaction, the non-uniformity of the geometry of the LithoAsthenospheric boundary (LAB) may play a critical role. The continental lithosphere $(\mathrm{CL})$ is thicker under the cratons $(>200)$ but relatively thinner beneath the mobile belt (150-70 km, depending upon its tectonic age). The undulation due to a significant difference in thickness, would obviously facilitate the decompressional melting (from an upwelling asthenosphere) into and along the thinner mobile belt part of the CL. It clearly implies that the thermal energy (heat) and magmatic phase would be focused (or guided) along the thinner mobile belts (which often represent the palaeo-boundaries). This concentration of reactivation along the mobile belts has been termed as chaneling of the Thermo-Magmatic Flux (TMF). This is strongly supported by the conspicuous concentration of geophysical anomalies and tectonic/geological features evidenced all along the Indian mobile belt network (Raval, 1995). A number of such reactivations would gradually make the MBs weaker which implies that their vulnerability to episodic re- juvenations would eventually bring the mobile belts to the critical state while it becomes quite prone to rifting/breakup.

The contrasting properties of cratons and mobile belts make a lithosphere strongly heterogeneous, both laterally as well as vertically. An example of this is the significant difference in observed heat transfer or thermal blanketing. Such heterogeneities would obviously govern the geodynamics and tectonic development of the lithosphere.

\section{Geophysical and Tectonic Evidence of Channel- ing}

Geological and geochemical characteristics can provide direct manifestation of the Plume-CL interaction (Wilson, 1989; Hoffman, 1997). However, if the latter is intense enough, then it is possible that the deep geophysical structures of the CL may also become modified, as has been inferred from deep geophysical probings.

(a) Density structure: The Bouguer gravity anomalies (NGRI, 1975) over India (Fig. 1(a)) seem to be confined mostly to the MBs (Raval, 1995). Figure 2(a) shows the density-depth profiles for different MB-regions delineated from deep seismic and gravity investigations (Tewari et al., 1991, 1997; Mishra et al., 1995); as well as for the Dharwar craton (Kaila and Bhatia, 1981). It reveals a high density layer (2.85-3.15 g/cc) beneath MBs (Fig. 1(a)) — a reflection of magmatic underplating. MBs (Fig. 1(a)) thus represent corridors of greater extension and eventual rifting. As in the case of most of the orogenic (or mobile) corridors, the temporal duration of the magmatic underplating evidenced here may be somewhat difficult to constrain. As a matter of fact, a geophysical anomaly in the deep crust would be the superposition of many thermomechanical and tectonomagmatic episodes that would have affected the continental litho- 


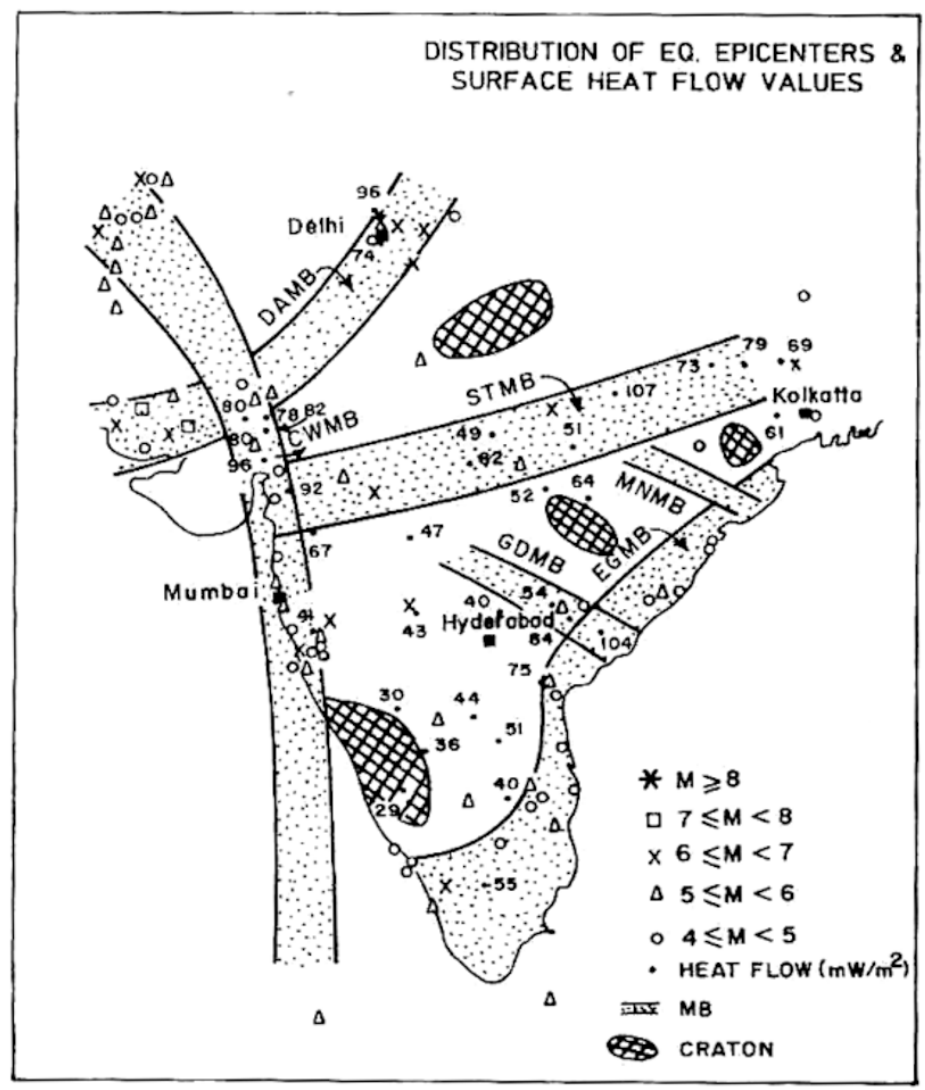

Fig. 2(b). Surface heatflow values and epicenters of seismic disturbance over the I-CL also show a concentration of seismic deformation and higher heatflow in the MBs (modified from Khattri et al., 1987; Ravishanker, 1988; Gupta et al., 1989).

sphere during its long geological history. Separation of the timings of various temporal contributions from the observed anomaly/image is indeed a formidable task. However, there could be much indirect but substantial evidence (geological, geochemical and isotopic), which could constrain the timings. More specifically, in the present case, the orogenic corridor is of the Proterozoic period, whereas a number of alkaline complexes (Bose, 1980; Krishnamurthy and Udas, 1981; Sethna, 1989; Srivastava, 1989; Subrahmanyam and Leelanandam, 1989; Rathore and Venkatesan, 1991; Basu et al., 1993; Dessai, 1994; Anil Kumar et al., 2003) having ages between 120-50 Ma, have been reported along various mobile belts affected by the plume activity. The ages of large igneous provinces (Rajmahal, Madagascar-South India and Deccan traps) by Ar-Ar methods (Basu et al., 1993; Baksi, 1994, 1995; Storey et al., 1995; Radhakrishna et al., 1999; Anil Kumar et al., 2001) also lie between Cretaceous to early Tertiary times.

Further, these alkaline complexes are associated with relatively long wavelength gravity highs (Tewari et al., 1991; Raval and Veeraswamy, 1997; Suryaprakasa Rao, 2003) and are strongly suggestive of deep-seated magmatic underplating which is also corroborated by the cospatial high velocity layer inferred by deep seismic studies (Tewari et al., 1991; Singh and Meissner, 1995). In addition, these corridors, which were affected by the crust-mantle interaction, also exhibit tectonic uplift which, according to McKenzie (1984), is caused by magmatic underplating. Thus, some evidence points out that magmatic underplating has occurred deep in the mobile belt regime of the Indian plate, since the Cretaceous.

(b) Seismic wave velocity structure: The high density structure is corroborated by coincident high seismic wave velocity (6.8-7.2 km/s) inferred (Fig. 2(a)) at the mid-to-lower crustal depths (Kaila et al., 1990; Tewari et al., 1997). Cretaceous volcanism obtained from the lithologies in the oil wells of Mahanadi MB (Fig. 1(a)), also suggest plume-induced crust-mantle interaction (Tewari, 1998). A high velocity deep crust is inferred beneath the Bengal basin too (Kaila et al., 1992), which also exhibits a gravity high anomaly ( $\sim 20 \mathrm{mgal}$ ) sub-parallel to $90^{\circ} \mathrm{E}$ ridge. These features obviously reflect modification of the crustal properties following interaction between this part of Indian CL and the Kerguelen/Crozet plumes that resulted in the LIP consisting of the Rajmahal/Sylhet/Bengal traps. Analysis of DSS results (Mall et al., 1999, Fig. 3)-reveals (i) an up to $10 \mathrm{~km}$ thick volcanic layer $(V p=4.8 \mathrm{~km} / \mathrm{s})$ beneath recent sediments, and (ii) an $\sim 4 \mathrm{~km}$ thick underplating $(V p=7.5 \mathrm{~km} / \mathrm{s})$ near Moho which is also deduced from the plume-CL interaction. The presence of high velocity and high density crustal layers within the MB and away from the center of the plume outburst (Fig. 1(a)) supports channeling and partitioning of the TMF along MB (Fig. 1(a)). Long distance channeling of TMF from a plume head was also suggested by Sleep (1996), and applied to the African continent (Ebinger and Sleep, 1998).

(c) Electrical conductivity: Geomagnetic and magnetotelluric sounding studies (Arora et al., 1993; Rao et 


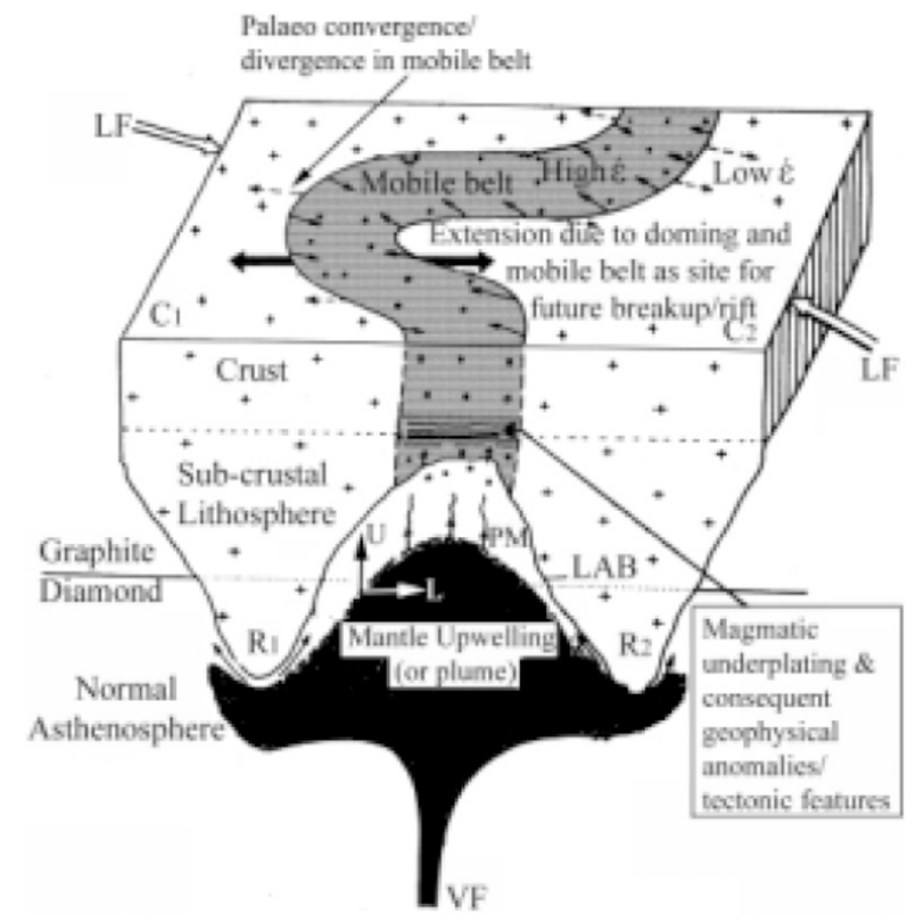

Fig. 3(a). The cartoon depicts the interaction of a mantle plume with a laterally heterogeneous (composite) continental lithosphere. Owing to the significant difference in the rheology, thickness and other properties, it is seen that the interaction between the plume and continental lithosphere is greater under the MBs as compared to cratonic block. Abbreviations: C1, C2-Cratonic blocks; MB-Mobile belt; R1, R2-Cratonic roots; VF-Vertical and LF-Lateral flow of the thermomagmatic flux.

al., 1995; Gautam Gupta et al., 1997) reveal conductivity anomalies over the Delhi-Aravali (DAMB) and Satpura (STMB) MBs. Similar higher electrical conductivity in the regions of Phanerozoic mobilization, suggests the presence of fluids released from thermal reactivation (Hyndman, 1988); thus the conductivity anomalies could corroborate plume-CL interaction.

(d) Surface Heatflow: From Fig. 2(b) high surface heatflow manifests mostly along the MBs (Raval, 1989). As discussed, the difference in the properties of cratons and MBs results in heterogeneous blanketing of the internal heat. The remobilizations could replenish the crust resulting in higher heat generation along MBs, which also form corridors of hot springs. Lowman and Jarvis (1999) also suggest that the mantle heating mode and history of continental assemblages (MBs) affect the location of continental rifting. Higher mantle heat flow has recently been reported from the MB in the southernmost part of the subcontinent (Rao and Srinivasan, 2000); it represents a terrain boundary and breakups (at $\sim 130$ and $90 \mathrm{Ma}$ ) and plume activity ( $\sim 90$ and 65-60 $\mathrm{Ma}$.

(e) Tectonics: Since TMF is facilitated by the MBs, implying that stresses, faults, fractures and dyke emplacements during extension, would be focused along the MBs (Fig. 1(a)) and act as conduits for volatiles and heat. This is supported by the concentration of hotsprings, seismicity along MB (Fig. 2(b)) rifting, sedimentation (subsidence) and uplifts along the $\mathrm{MBs}$ - a sort of rheological wave-guide. The term wave-guide has been used here for clearer visualization of the litho-asthenosphere interaction. This is because, as is well known, in the case of a wave-guide, most of the energy flux (elastic, sound or electromagnetic) remains confined. Similarly in the present case, the thermomagmatic flux (the heat energy and the magmatic activity) seems to be channeled mostly along the base of the mobile belt lithosphere (please see Fig. 3(a)). Lowman and Jarvis (1999) have used similar argument to explain the stability of the supercontinents. Thybo et al. (2000) also show that similar focusing of seismicity is evidenced across the craton-MB transition between the western region (mobile type) and eastern/central cratonic parts of North America.

\section{Composite Continental Lithosphere and Waveg- uide Type Transcontinental MBs}

Figure 3(a) sketches interaction between a composite lithosphere and mantle (or plume) upwelling. If it is kept in mind that there is a significant difference in the lithospheric thicknesses under the Archaean cratons (180-300 km) and the mobile belt $(70-180 \mathrm{~km})$ parts of the continental lithosphere, then the mantle upwelling will evidently have a much easier upward passage due to far greater decompressional melting that follows from the shallow base under the mobile belts. On the other hand, near the base of the deep rooted cratons, the partial melting would be meager due to large pressure at those depths. These differences explain the undisturbed nature of cratons and the relatively vulnerable nature of the mobile belts which allow the channeling of thermomagmatic flux and, hence, manifestation of most of the geological, geophysical, geochemical and tectonic signatures. The rigid and refractory nature of the cratonic base resists the diffusion of thermomagmatic flux, which therefore moves towards the adjoining and thinner MBs (Fig. 3(a)). This partitioning makes the splitting of craton less probable, while a thinner (80-150 km) MB-lithosphere allows larger 


\section{Trascontinental mobile belts and Hotspots}

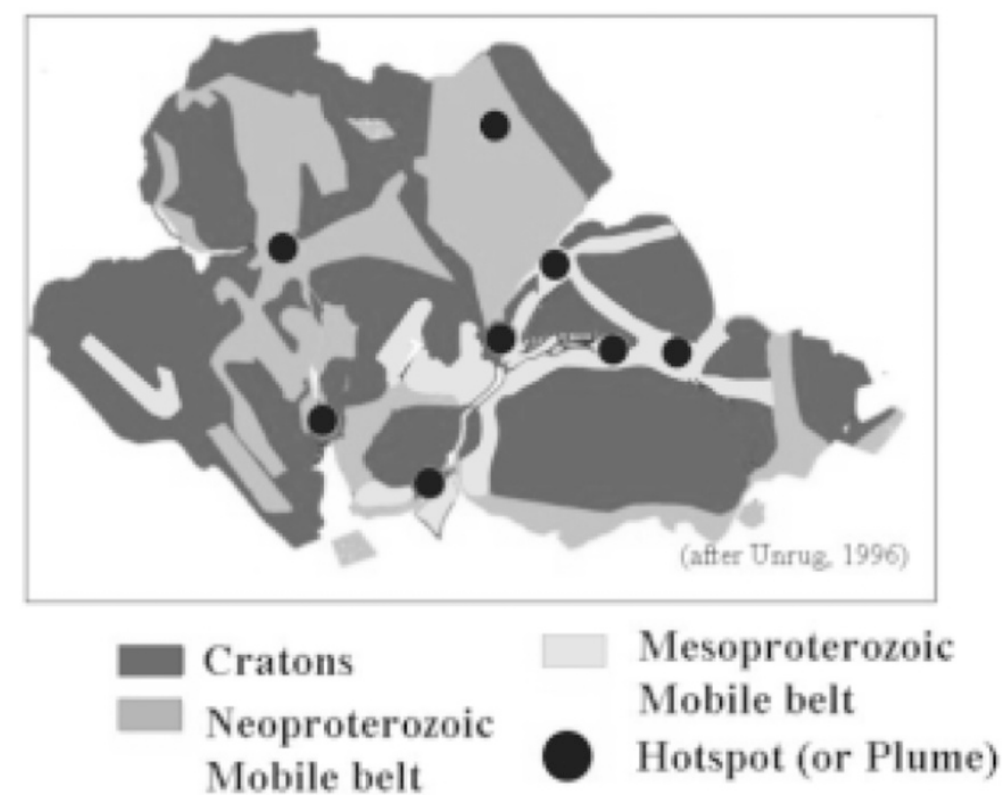

Fig. 3(b). Transcontinental Mobile belts (modified from Unrug, 1996) and position of hotspots.

decompressional melting and long-distance channeling; alternatively, MBs help in maintaining cratonic stability (Lowman and Jarvis, 1999).

In the case of ongoing mantle convection (both in plate and plume mode; Davies, 1999) the shallow base of the lithosphere under the mobile belts could facilitate large-scale mantle upwelling (both passive and active types). The active upwelling could be due to a mantle plume coming under the lithospheric plate. It has been shown by Crough $(1979,1983)$ that every lithospheric plate passes over a mantle plume approximately every $530 \mathrm{~m}$.y. Hence, for a 1-3 Ga continental lithosphere mantle, upwelling would apparently become an episodic process. Recently, Condie (2001) outlined four time zones of large crustal growth governed by superplume activity. Abbot et al. (1997) have also delineated certain longperiod episodicity of plume-lithosphere interactions.

The presence of intraplate magmatism of different ages, e.g. Archaean komatiites and alkaline rocks and associated tholeiites of different age groups $(1600,1100,800,120$ and $60 \mathrm{Ma}$ ) over the Indian subcontinent (Naqvi and Rogers, 1987), provide sufficient evidence for the episodic nature of the interaction between plume and Indian continental lithosphere. As discussed earlier, each time a mantle plume impinges at the base of the mobile belt lithosphere, the resulting channeling of the thermomagmatic flux along the mobile belt would weaken it so that it eventually reaches a critical stage where the next upwelling of sufficient strength can result in a continental breakup along the mobile belt (Vauchez et al., 1997; Raval and Veeraswamy, 2003). Further partial melting, near the deep-rooted cratonic base, may be much less (Davies, 1999) and, being rigid and refractory, it resists the diffusion of TMF, which therefore moves towards the adjoining, thinner MBs (Fig. 3(a)). This partitioning makes splitting of the craton less probable, while a thinner (80-150 km) MB lithosphere allows larger decompressional melting and long-distance channeling; alternatively MBs help in maintaining cratonic stability (Lowman and Jarvis, 1999). Episodic upwellings make MB lithospheres gradually thinner and, in turn, greater decompressional melting follows. Melting increases if the MB is hydrous which, in some cases, gives rise to LIP/CFB (Gallagher and Hawkesworth, 1992; Courtillot et al., 1999). This process finally leads to a greater probability of breakup along the MBs. With respect to geochemical/isotopic signatures along the MBs, it may be noted that the asthenospheric mantle underlying the CL is normally depleted (DM), but anomalously hot and enriched (EM) in the case of plume upwelling from a deep mantle.

Thus, if the litho-asthenosphere boundary (LAB) beneath the MB becomes optimally shallow due to episodic mobilizations, and the concentration of heat and fluids make MBs weak enough, then extension due to doming caused by the asthenospheric upwelling could cross the threshold-breaking strength of the MB lithosphere. But, the relatively cold, dry and deep-rooted cratonic lithosphere escapes this process and, hence, remains largely intact. These MBs could be graded with respect to the time lapsed since their last rejuvenation, thus first-order MBs would characterize recent reactivation, while for higher-order MBs much longer time would have lapsed since the last mobilization. Alternatively, higher-order MBs tend to become cratonized.

Combination of first-order MBs (Unrug, 1996) and plumes which characterize the breakups of Greater India, as discussed earlier, seems globally applicable because supercontinental splitting also appears to be guided by the transcontinental MBs (Fig. 3(b)). In a few cases, however, the breakup has not occurred despite plume activity (e.g. Siberial flood basalt) probably due to the association of higher-order MBs (i.e. which are thicker and stronger or rela- 


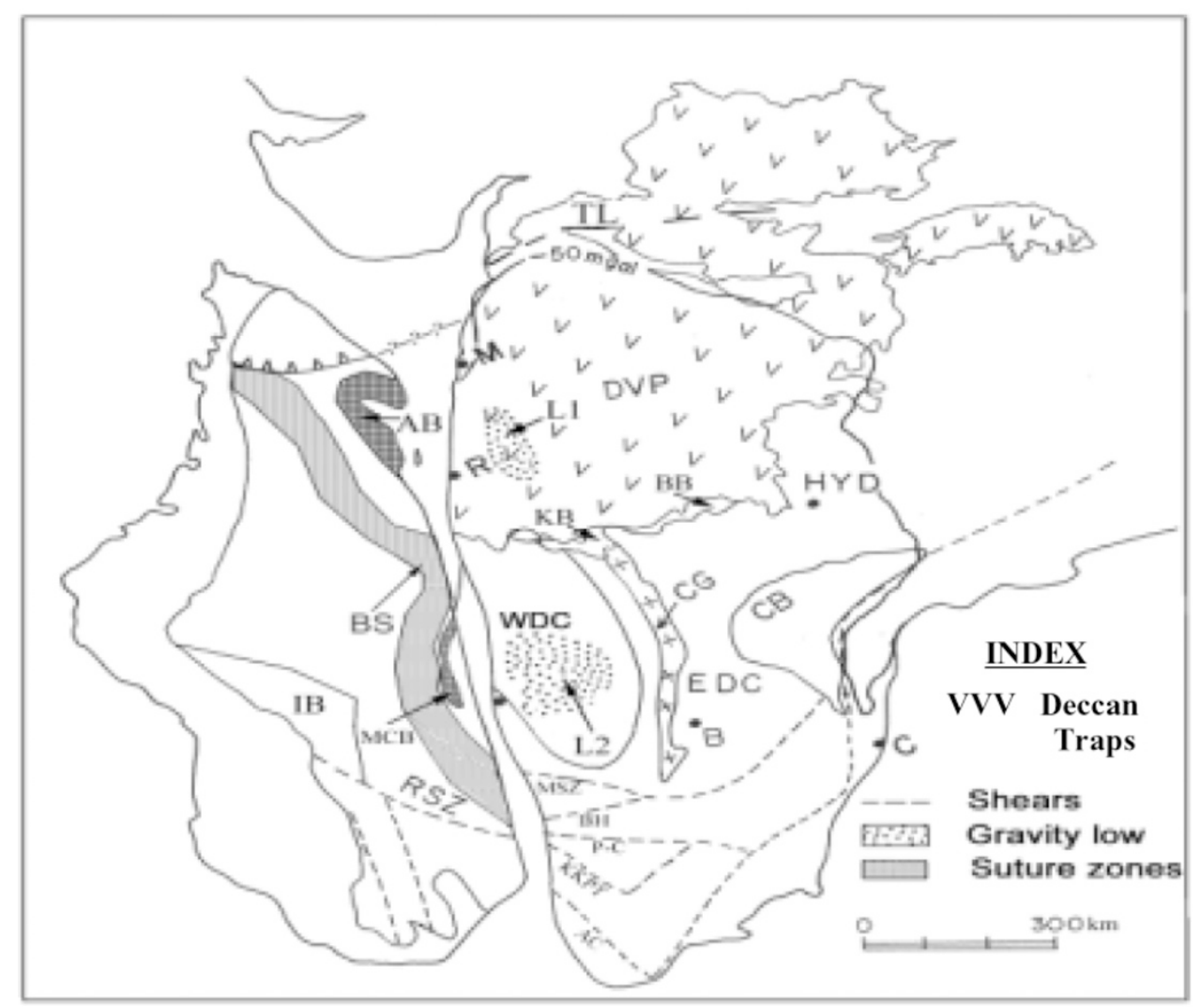

Fig. 4. Juxtapositioning — on combining the geophysical anomalies with structural elements—of India-Madagascar before its breakup (>90 Ma). It also shows major shear zones and regions of large Bouguer gravity. Abbreviations are B-Bangalore, C-Chennai, HYD-Hyderabad, M-Mumbai, $\mathrm{Mg}$-Mangalore, $\mathrm{R}$ - Ratnagiri and TL_-Tapti lineament.

tively cratonized). This is corroborated by the fact that while the Neoproterozoic Mozambique belt gave way during the Karoo actizty and breakup, the late Archaean Limpopo belt, between the Zimbabwe and Kaapvaal cratons, remained intact. Large-distance lateral channeling along transcontinental MBs explains the global scale propagation of mega thermomagmatic episodes. For example, the Pan African event is evidenced over Madagascar, the Seychelles, MBs of India (Fig. 1(a)), Srilanka, Antarctica, etc. Similarly, TMF from the Karroo event traversed up to Tasmania via the Antarctic mobile corridor (Duncan et al., 1997).

\section{Chipping of the Craton}

Normally, old cratons with their tectospheric keel have remained undisturbed since the Archaean (or early Proterozoic) period. However, at the edges of a craton where it meets the boundary (or suture) corridor consisting of a mobile belt, the edges of the craton are likely to be affected because of the episodic activations, of the mobile belts. In such situations, edges of cratons (in this case, the western part of the Dharwar craton) may become relatively weakened as compared to the core (or central part) of the craton. This process can, in turn, increase the probability of the cratonic edges getting chipped away during a breakup. This seems to be the case with regard to the Antongil and Masora cratonic strips that appear to have formed the western edge of the Dharwar craton before the separation of Madagascar from India at $\sim 90$ Ma.

The India-Madagascar separation, as discussed above, seems to be governed by the mobile nature of the Madagascan lithosphere barring the two thin strips (viz. Antongil and Masora blocks) of Archaean age and low-grade facies. From Fig. 4 these two strips appear to be the westernmost edge of the WDC. Owing to its mobile belt type, Madagascar would be relatively thinner and weaker and, hence, vulnerable to episodic reactivations. This implies that during this process, the westernmost edge of the WDC would have also become affected and weaker. On the other hand, greater lithospheric thickness $(d \sim 250 \mathrm{~km})$ under the WDC resists these episodic thermomagmatic fluxes, leaving its margins undisturbed and stable. The difference in the response between WDC and Madagascar arises because a thermal upwelling under a lithosphere consisting of craton and mobile belts would mostly affect the younger and relatively weaker (mobile) corridors first. The partial melting and channeling of TMF will be concentrated near the cratonic edges which, if it becomes sufficiently weakened, might also get chipped off the craton, as seems to be the case where the Antongil and Masora blocks form the westernmost edges of WDC and were chipped out due to episodic reactivation of the Madagascan lithosphere (Fig. 4).

\section{Concluding Remarks}

On the basis of geophysical and geotectonic data and palaeo-juxtapositioning, this study tries to show that examination of the dispersal undergone by the mobile network of Greater India since the early Cretaceous, provides a very useful insight into the understanding of superconti- 
nental breakups, particularly into where and how they rifted apart.

Owing to significant difference in the thickness, thermal state and rheology of cratons and mobile belts, their thermomechanical response to impressed tectonothermal forces (due to plate or plume tectonics) would vary substantially. The mobile belts facilitate through them the channeling of thermomagmatic flux, while cratons resist the rejuvenation and episodicity of such events, thus eventually bringing the mobile belts to a critical state. In this state, the presence of an intense enough plume can be fatal for the stability of a supercontinent.

The transcontinental mobile belts exhibit a wave-guide type effect by allowing a large-distance migration along them of the tectonothermal forces. The deep rooted refractory and cold craton, on the other hand, remains mostly intact except in a few cases where the cratonic edges also become affected by the episodic reactivations of the adjoining mobile belts, as exemplified here by the India-Madagascar and Africa-Antarctica separations.

Acknowledgments. One of us (K.V.) is grateful to the Director of NGRI for permission to publish this study. We are thankful to the two referees for making many valuable comments that have substantially improved the manuscript. Thanks are also due to Prof. Y. Honkura for his valuable suggestions which have greatly improved the presentation.

\section{References}

Abbot, D. H., R. Drury, and W. D. Mooney, Continents as lithological icebergs: the importance of buoyant lithospheric roots, Earth Planet. Sci. Lett., 149, 15-27, 1997.

Anil Kumar, K. Pande, T. R. Venkatesan, and Y. J. Bhaskar Rao, The Karnataka late Cretaceous dykes as products of the Marion hotspot at the Madagascar-India breakup event: evidence from ${ }^{40} \mathrm{Ar}-{ }^{39} \mathrm{Ar}$ geochronology and geochemistry, Geophys. Res. Lett., 28, 2715-2718, 2001.

Anil Kumar, A. M. Dayal, and V. M. Padmakumari, Kimberlite from Rajmahal magmatic province: $\mathrm{Sr}-\mathrm{Nd}-\mathrm{Pb}$ isotopic evidence for Kerguelen plume derived magmas, Geophys. Res. Lett., 30, 18462-18465, 2003.

Arora, B. R., P. Kaikkonen, M. V. Mahashabde, and S. Y. Waghmare, A non uniform thinsheet model for geomagnetic induction anomalies in central India, Physics of the Earth and Planet. Inter., 81, 201-213, 1993.

Atchuta Rao, D., G. D. J. Sivakumar Sinha, and H. V. Ram Babu, Modelling of aeromagnetic anomaly and its implication on age of emplacement of ultramafic-mafic-alkaline complex at Jasra, Assam, Current Science, 66, 58-60, 1996.

Baksi, A. K., Geochronological studies on whole-rock basalts, Deccan traps, India: evaluation of the timing of volcanism relative to the K-T boundary, Earth Planet. Sci. Lett., 121, 43-56, 1994.

Baksi, A. K., Petrogenesis and timing of volcanism in the Rajmahal flood basalt province, northeastern India, Chemical Geology, 121, 73-90, 1995.

Basu, A. R., P. R. Renne, D. K. Das Gupta, F. Teichmann, and R. J. Poreda, Early and late alkali igneous pulses and a high $-{ }^{3} \mathrm{He}$ plume origin for the Deccan flood basalts, Science, 261, 902-906, 1993.

Biswas, S. K., Regional tectonic framework, structure and evolution of the western marginal basins of India, Tectonophysics, 134, 307-327, 1987.

Bose, M. K., Alkaline magmatism in the Deccan volcanic province, J. Geol. Soc. India, 21, 317-329, 1980.

Burke, K. and J. F. Dewey, Plume-generated triple junctions: Key indicators in applying plate tectonics to old rocks, J. Geology, 81, 406-433, 1973.

Campbell, I. H. and R. W. Griffiths, Implications of mantle plume structure for the evolution of flood basalts, Earth Planet. Sci. Lett., 99, 79-93, 1990.

Collins, A. S. and B. F. Windley, The tectonic evolution of central and northern Madagascar and its place in the final assembly of Gondwana, J. Geology, 110, 325-339, 2002.

Collins, A., B. Windley, A. Kroner, I. Fitzsimons, and B. Hulscher, The tectonic architecture of central Madagascar: Implication on the evolution of the east African orogeny, Gondwana Research, 4, 152-153, 2001.
Condie, K. C., Mantle Plumes and Their Record in Earth History, Cambridge Univ. Press, Cambridge, 2001.

Courtillot, V., C. Jaupart, I. Manighetti, P. Tapponnier, and J. Besse, On causal links between flood basalts and continental breakup, Earth Planet. Sci. Lett., 166, 177-195, 1999.

Courtillot, V., Y. Gallot, R. Rocchia, G. Ferand, E. Robin, C. Hofmann, N. Bhandari, and Z. G. Ghevariya, Cosmic markers, ${ }^{40} \mathrm{Ar} /{ }^{39} \mathrm{Ar}$ dating and paleomagnetism of the KT sections in the Anjar area of the Deccan large igneous province, Earth Planet. Sci. Lett., 182, 137-156, 2000.

Crough, S. T., Hotspot epirogeny, Tectonophysics, 61, 321-333, 1979.

Crough, S. T. Hotspot swells, Ann. Rev. Earth Planet. Sci., 11, 165-193, 1983.

Dalziel, I. W. D., L. A. Lawver, and J. B. Murphy, Plumes, orogenesis, and supercontinental fragmentation, Earth planet. Sci. Lett., 178, 1-11, 2000.

Davies, G. F., Dynamic Earth Plate, Plume and Mantle Convection, Cambridge Univ. Press, pp. 458, 1999.

Dessai, A. G., Magma fractionation and mixing in Nephelinite plug association with Deccan magmatism at Murud-Janjira, south of Bombay, $J$. Geol. Soc. India, 43, 493-509, 1994.

Dunbar, J. A. and D. S. Sawyer, How preexisting weaknesses control the style of continental breakup, J. Geophys. Res., 94, 7278-7292, 1989.

Duncan, R. A., P. R. Hooper, J. Rehacak, J. S. Marsh, and A. R. Duncan, The timing and duration of the Karoo igneous event southern gondwana, J. Geophys. Res., 102, 18127-18138, 1997.

Ebinger, C. J. and N. H. Sleep, Cenozoic magmatism throughout east Africa resulting from impact of a single plume, Nature, 395, 788-791, 1998.

Ernst, R. E. and K. L. Buchan, Mantle plumes: Their identification through time, Geol. Soc. Am., Spl. Paper, 352, 593, 2001.

Fourno, J. P., Contribution a letude de la discontinuite de Mohorovicic dapres les ondes sismiques observees a Madagascar, Annales Geophysicae, 5, 175-186, 1987.

Gallagher, K. and C. Hawkesworth, Dehydration melting and the generation of continental flood basalts, Nature, 358, 57-59, 1992.

Gautam Gupta, C. K. Rao, and S. G. Gokarn, Deep geoelectric structure in the Rohtak region using the magnetotelluric studies, J. Geol. Soc. India, 50, 697-708, 1997.

Groenewald, P. B., G. H. Grantham, and M. K. Watkeys, Geological evidence for a Proterozoic to Mesozoic link between southeastern Africa and Dronning Maud land, Antarctica, J. Geol. Soc. London, 148, 11151123, 1991.

Gupta, M. L., S. R. Sharma, and A. Sundar, Heatflow map of India, N. G. R. I. (unpublished), 1989.

Gupta, S., S. S. Rai, K. S. Prakasam, D. Srinagesh, R. K. Chadha, K. Priestley, and V. K. Gaur, First evidence for anomalous thick crust beneath mid-Archaean western Dharwar craton, Current Science, 84, 1219-1226, 2003.

Hoffman, A. W., Mantle geochemistry: the message from oceanic volcanism, Nature, 385, 219-229, 1997.

Hyndman, R. D., Dipping seismic reflectors, electrically conductive zones and trapped water in the crust over a subducting plate, J. Geophys. Res., 93, 13391-13405, 1988.

Kaila, K. L. and S. C. Bhatia, Gravity study along the Kavali-Udipi deep seismic sounding profile in the Indian peninsular shield: Some inferences about the origin of anorthosites and the eastern ghats orogeny, Tectonophysics, 79, 129-143, 1981.

Kaila, K. L., H. C. Tewari, V. G. Krishna, M. M. Dixit, D. Sarkar, and M. S. Reddy, Deep seismic sounding studies in the north Cambay and Sanchor basins, India, Geophys. J. Int., 103, 621-637, 1990.

Kaila, K. L., P. R. Reddy, D. M. Mall, N. Venkateswaralu, V. G. Krishna, and A. S. S. S. R. S. Prasad, Crustal structure of the West Bengal basin, India from Deep Seismic Sounding investigation, Geophys. J. Int., 111, 45-66, 1992.

Kent, R., Lithospheric uplift in eastern Gondwana: Evidence for a long-lived mantle plume system?, Geology, 19, 19-23, 1991.

Khattri, K. N., A. M. Roger, D. M. Perkin, and S. T. Algemlissen, A seismic hazard map of India and adjacent areas, Tectonophysics, 108, 93-134, 1987.

Krishnamurthy, P. and G. R. Udas, Regional geological characteristics of the Deccan trap basalts and their genetic implications, Mem. Geol. Soc. India, 3, 394-418, 1981.

Larson, R. L., Latest pulse of earth: Evidence for a mid-Cretaceous superplume, Geology, 19, 547-550, 1991a.

Larson, R. L., Geological consequences of superplumes, Geology, 19, 963966, $1991 b$.

Lowman, J. P. and G. T. Jarvis, Effects of mantle heat source distribution on 
supercontinent stability, J. Geophys. Res., 104, 12733-12746, 1999.

Mahoney, J. J., R. A. Duncan, W. Khan, E. Gnos, and G. R. McCormick, Cretaceous volcanic rocks of the south Tethyan suture zone, Pakistan: Implications for the Reunion hotspot and Deccan traps, Earth Planet. Sci. Lett., 203, 295-310, 2002.

Mall, D. M., V. K. Rao, and P. R. Reddy, Deep subcrustal features in the Bengal basin: seismic signatures of plume activity, Geophys. Res. Lett., 26, 2545-2548, 1999.

McKenzie, D., A possible mechanism for epirogenic uplift, Nature, 307, 616-618, 1984.

Mishra, D. C., G. Laxman, M. B. S. V. Rao, and S. B. Gupta, Analysis of the gravity-magnetic data around Nagaur-Jhalawar geotransect, Mem. Geol. Soc. India, 31, 345-357, 1995.

Mishra, D. C., D. V. Chandra Sekhar, D. Ch. Venkata Raju, and V. Vijaya Kumar, Crustal structure based on gravity-magnetic modelling constrained from seismic studies under Lambert rift, Antarctica and Godavari and Mahanadi rifts, India and their interrelationship, Earth Planet. Sci. Lett., 172, 287-300, 1999.

Morgan, W. J., Convention in plumes in the lower mantle, Nature, 230, 4243, 1971.

Mukhopadhyay, M., Current seismicity in Northern Maharashtra and Southern Gujarat: Implications of Plume Tectonics, J. Geol. Soc. India, 60, 629-637, 2002.

Naqvi, S. M. and J. J. W. Rogers, Precambrian Geology of India, Oxford University Press, New York, pp. 223, 1987.

NGRI, Bouguer Gravity Anomaly Map of India. 1:5,000,000 Scale, 1975.

Radhakrishna, B. P. and S. M. Naqvi, Precambrian continental crust of India and its evolution, J. Geology, 94, 145-166, 1986.

Radhakrishna, T., H. Maluski, J. G. Mitchell, and M. Joseph, ${ }^{40} \mathrm{Ar} /{ }^{39} \mathrm{Ar}$ and $\mathrm{K} / \mathrm{Ar}$ geochronology of the dykes from the south Indian granulite terrain, Tectonophysics, 304, 109-129, 1999.

Rao, C. K., S. G. Gokarn, and B. P. Singh, Upper crustal structure in the Torni-Purnad region, central India using magnetotelluric studies, $J$. Geomag. Geoelectr., 47, 411-420, 1995.

Rao, R. U. M. and R. Srinivasan, Geothermal regime and radioelemental distribution in the southern granulite terrane, Project completion Report submitted to DST, pp. 49, 2000.

Rathore, S. S. and T. R. Venkatesan, ${ }^{40} \mathrm{Ar}^{-39} \mathrm{Ar}$ Age of Essexite from Mundwara Alkaline Complex, S Rajasthan, India. Abstract, Fifth National Symposium on Mass Spectrometry, Ahmedabad, India, pp. EPS-II/I-II/3, 1991.

Raval, U., On hotspots, Meso-Cenozoic tectonics and possible thermal networking beneath the Indian continent, Proc. of the Ind. Geophys. Union Seminar, Hyderabad, India, 314-330, 1989.

Raval, U., Geodynamics of the tectonomagmatic and geophysical signatures within mobile parts of the transect, Mem. Geol. Soc. India, 31, 37-61, 1995.

Raval, U., Use of interaction between mantle plume and a continental lithosphere in search of gold and diamonds, AEG Seminar abstract volume, held at Nagpur during 28-31 October, 1998.

Raval, U. and K. Veeraswamy, Investigations on the electrical structures across and along the Narmada-Son lineament and its tectonic implications, Geological Survey of India Misc. Publ. 63, 62-76, 1997.

Raval, U. and K. Veeraswamy, The radial and linear modes of interaction between mantle plume and continental lithosphere: A case study from western India, J. Geol. Soc. India, 56, 525-536, 2000.

Raval, U. and K. Veeraswamy, India-Madagascar separation: Breakup along pre-existing Mobile Belt and chipping of the craton, Gondwana Research, 6, 467-485, 2003.

Ravikumar, M., J. Saul, D. Sarkar, R. Kind, and A. K. Shukla, Crustal structure of the Indian shield: New constraints from teleseismic receiver functions, Geophys. Res. Lett., 28, 1339-1342, 2001.

Ravishanker, Heat-flow map of India and discussions on its geological and economic significance, Indian Minerals, 42, 89-110, 1988.

Roy, A. B., The Phanerozoic reconstruction of Indian shield as the after- math of breakup of the Gondwanaland, Gondwana Research, 7, 387-406, 2004.

Sethna, S. F., Petrology and geochemistry of the acid, intermediate and alkaline rocks associated with the Deccan basalts in Gujarat and Maharashtra, Mem. Geol. Soc. India, 15, 47-61, 1989.

Singh, A. P. and R. Meissner, Crustal configuration of the Narmada-Tapti region (India) from gravity studies, J. Geodynamics, 20, 111-127, 1995.

Sivaraman, T. V. and U. Raval, U-Pb isotopic study of zircons from a few granitoids of Delhi-Aravalli belt, J. Geol. Soc. India, 46, 461-475, 1995.

Sleep, N. H., Lateral flow of hot plume material ponded at sublithospheric depth, J. Geophys. Res., 101, 28065-28083, 1996.

Srinagesh, D., Teleseismic tomographic evidence for contrasting crust and upper mantles beneath Archaean and Phanerozoic terrains in south India, Visakha Science J., 4, 97-105, 2000.

Srivastava, R. K., Alkaline and peralkaline rocks of Rajasthan, Mem. Geol. Soc. India, 15, 3-24, 1989.

Storey, B. C., The role of mantle plumes in continental breakup: case histories from Gondwanaland, Nature, 377, 301-308, 1995.

Storey, M., J. J. Mahoney, A. D. Saunders, R. A. Duncan, S. P. Kelly, and M. F. Coffin, Timing of hotspot related volcanism and the breakup of Madagascar and India, Science, 262, 852-855, 1995.

Subrahmanyam, N. P. and C. Leelanandam, Differentiation due to probable initial immiscibility in the Musala pluton of the Mundwara alkaline igneous complex, Rajasthan, India, Mem. Geol. Soc. India, 15, 25-46, 1989.

Suryaprakasa Rao, G., Crustal seismic velocity structure from synthetic seismogram modeling of DSS record sections in the Saurashtra peninsula, Unpublished Ph.D. Thesis, Osmania University, pp. 133, 2003.

Tewari, H. C., The effect of thin high velocity layers on seismic refraction data: An example from Mahanadi basin, India, Pageoph., 151, 63-79, 1998.

Tewari, H. C., M. M. Dixit, D. Sarkar, and K. L. Kaila, A crustal density model across the Cambay basin, India, and its relationship with the Aravallis, Tectonophysics, 194, 123-130, 1991.

Tewari, H. C., M. M. Dixit, N. Madhava Rao, N. Venkateswaralu, and V. Vijaya Rao, Crustal thickening under the Paleo-meso-Proterozoic Delhi fold belt in northwestern India: evidence from deep reflection profiling, Geophys. J. Int., 129, 657-668, 1997.

Tewari, H. C., A. S. N. Murty, Prakash Kumar, and A. R. Sridhar, A tectonic model of the Narmada region, Current Science, 80, 873-878, 2001.

Thybo, H., E. Perchuc, and S. Zhou, Intraplate earthquakes and a seismically defined lateral transition in the upper mantle, Geophys. Res. Lett., 27, 3953-3956, 2000.

Tommasi, A. and A. Vauchez, Continental rifting parallel to ancient collisional belts: an effect of the mechanical anisotropy of the lithospheric mantle, Earth Planet. Sci. Lett., 185, 199-210, 2001.

Tucker, R. D., L. D. Ashwal, and T. H. Torsvik, U-Pb geochronology of Seychelles granitoids: a neoproterozoic continental arc fragment, Earth Planet. Sci. Lett., 187, 27-38, 2001.

Unrug, R., The assembly of Gondwanaland, Episodes, 19, 11-20, 1996.

Vauchez, A., G. Barruol, and A. Tommasi, Why do continents break-up parallel to the ancient orogenic belts?, Terra Nova, 9, 62-66, 1997.

Verma, R. K., Gravity Field, Seismicity and Tectonics of the Indian Peninsula and the Himalaya, D. Reidel Pub. Co., Dordrecht, pp. 213, 1985.

White, R. and D. McKenzie, Magmatism at rift zones: The generation of volcanic continental margins and flood basalts, J. Geophys. Res., 94, 7685-7729, 1989.

Wilson, J. T., A possible origin of Hawaian Islands, Canadian J. Physics, 41, 863-870, 1963.

Wilson, M., Igneous Petrogenesis, Unwyn Hyman, London, 466 pp., 1989.

Woollard, G. P., Regional variations in gravity, in The Nature of the Solid Earth, edited by E. C. Robertson, 463-505, 1972.

K. Veeraswamy (e-mail: kv_swamy@yahoo.com) and U. Raval 